lower current less than $\mathrm{I} \cdot 84$ and more than $3 \cdot 22$ feet per second. Mean velocity of the under current was $2 \cdot 32$.

The upper current does not everywhere occupy the full breadth of the strait. It flows in some places under the north coast of the strait, and in other places under the south coast. Lower current also does not flow over the whole breadth, and occupies a certain part of the bed of the strait. In my book I give a chart of the Bosporus, where I show direction of the upper and lower currents. A glance at that chart will show that there are places where both currents can be found, and there are places where the instrument will show the existence of only one of them, and in some places the explorer will not find either upper direct current or under current.

Difference of level of Black and Marmora Seas, calculated from difference of specific gravity of water, is I foot 5 inches. Mean specific gravity of water $\left(\mathrm{S}_{i 7 \cdot 5}^{17.5}\right)$ entering from the Black Sea into the Bosporus is $\mathrm{r}$ or 40 . Mean specific gravity of water entering from the Marmora into the Bosporus is $\mathrm{I} \cdot 0283$.

By upper current pass 370,000 cubic feet per second. By lower current pass 200,000 feet per second. Difference between these two figures being 170,000 feet per second is due to the excess of fresh water in the Black Sea.

I hope that after reading these figures and deductions Admiral Wharton will change his opinion, and come to the conclusion that my idea about double current in the Bosporus is based, not only on theoretical considerations, but also upon direct measurement.

Admira Wharton expresses also his opinion about double current of the strait of Bab-el-mandeb, and says that "there are none of the differences of specific gravity." I may be permitted to refer to my other book, "Le Vitiaz et l'Ocean Pacifique," where I give (p. 136, plate xxvii.) specific gravity of the strait of Bab-el-Mandeb measured by myself. Examination of figures given there by me shows that there is a difference of specific gravity which produces double current in that strait.

Nobody can deny that the wind has a great influence upon the movement of surface water; but I hope that Admiral Wharton will agree with me that differences of specific gravity has also some influence upon the circulation of water in the seas generally and in the straits particularly. S. MAKAROFF.

Ermack, Newcastle-upon-Tyne, September 23.

\section{Movement of Sea-Gulls with a Coming Change of Weather.}

THE suggestion that sea-gulls may have some meteorological sense would be best tested by inquiry as to whether there was, at the time of their westward flights, observed by your recent correspondents, any other possible motive for their journeys ; and particularly what food was available in the Channel at the time.

Neither of your correspondents needs to be told that every sea-gull is a semaphore to every other sea-gull in sight of him, nor that one gull "working on" fish will presently be surrounded by others from all sides.

In clear, fine weather the news of abundant sprats would be passed along the Channel in this way, faster than by military signallers, and answered by a concentration of gulls much speedier than any possible to troops.

Moreover these birds, and vultures, as I know from repeated observation, do not merely follow each other round the headlands. If a gull in a bay sees another gull hurrying from the offing into the next bay, he does not fly round the headland between, but rises over it, well knowing that from the upper air he will see whatever hurried the outer gull. As he does so his motions will be observed, and probably acted on by others further within the first bay; and if food be failing in the Thames, and abundant off the Wight, there will be plenty of gulls flying across Kent, and some across even Surrey. Here in Chelsea I seldom see large gulls on the river. But it is a common enough thing to see them flying high overhead to the southwest ward.

Westerly and south-westerly gales are so common in the Channel that neither beast nor bird can make any movement without a good off-chance of finding one on his way. It has to be remembered that most of our nigratory sea fish are apt to run 24. Channel in the warm half of the year, so that the message, "Plenty of fish on the surface," is probably most often passed from west to east.

$$
\text { NO. I } 562 \text {, voL. } 60]
$$

We shall, I think, need a good many simultaneous observ ations at various points and of various matters before we make it even probable that sea-gulls can foretell a south.west wind, and will then go to meet it. They cannot eat it ; and, if strong, it will give them little leave to eat anything else ; so the motive is not apparent.

IO2 Cheyne Walk, Chelsea, S.W., September 22.

\section{On the Use of the Fahrenheit Scale for Observations on Sea Temperatures.}

IN addition to the Fahrenheit scale being so much more practical for observation in meteorology than the Celsius, allow me to point out that in observations for ocean temperature it is even more so, and especially when we come to deal with ob. servations taken in the polar regions. Here with the Fahrenheit scale we have never to deal with a minus reading at all; whereas with the Celsius scale it is a constant change from plus to minus and minus to plus. This introduces a source of very serious error both in observation and calculation, besides adding to the work, and therefore the cost of working up results. The boon of never having to think of a minus in such work is not to be lost sight of for the sake of fashion. As one who has taken part in extensive observation and calculation work at Ben Nevis Observatory, on board ship, and in connection with the Scottish Fishery Board, I would also urge the use of the Fahrenheit scale for meteorological observations on the same grounds as Mr. J. Y. Buchanan and Mr. H. Helm Clayton.

Joppa, Edinburgh, September 25. William S. BRUCE.

\section{Cave Shelters and the Aborigines of Tasmania.}

I HAVE just received news from Mr. J. B. Walker, of Hobart, of the discovery of some interesting relics of the aborigines of Tasmania. Mr. Walker accompanied Mr. R. M. Johnston, the Government Geologist, on an expedition in search of some remains of Tasmanians, and the party were rewarded by finding a hitherto unknown so-called quarry where the natives manufactured some stone implements, also a cave which showed considerable evidence of having been used by the aborigines, as well as a tree notched by them for climbing purposes. The sandstone cave or rock shelter $i$ situated in Hutton Park, near Lovely Banks. The quarry is situated at Coal Hill, two miles north of Melton Mowbray, about 40 miles N.N.W. of Hobart, and I 100 feet above the sea-level.

The discovery of this quarry makes the tenth known quarry used by the aborigines, and the first mention of their use of cave or rock shelters.

Halifax (Yorks.), September 27.

H. LiNG Roth.

\section{The Darjeeling Disaster.}

UNUSUALLY large seismograms were obtained in the Isle of Wight on September 3, 10, 17, 20 and 23. The first three, refer to disturbances originating in Alaska. The fourth refers to disasters in As ia Minor, and the last to an earthquake having an origin as distant as Japan. Since the $23 \mathrm{rd}$ in the Isle of Wight, and I believe also at Kew, not the slightest movement has been recorded. The inference is that the great earthquakes reported as having taken place at Darjeeling on the night of September 25-26 are at the most small and local, and are not likely to have been recorded outside the Indian Peninsula. It is extremely likely that the tremors noticed in Darjeeling were due to landslides, and seismic phenomena were entirely absent.

Shide Hill Hou ie, Shide, Newport, Isle of Wight, J. MilNe. September 27.

\section{Lectures at the Royal Victoria Hall.}

I SEE in your issue of September 2I (p. 513) the statement that I am to lecture at the Royal Victoria Hall on "Photographs taken in the dark." I beg to say that the title I gave for my lecture was "Pictures taken on a photographic plate in the dark." I suppose the authorities at the Hall consider the titles identical. I do not.

St. Ives, Ringwood, Hants, September 26.
W. J. Russell. 